\title{
Flow Analysis and Heat Transfer of Nanofluid Flow in Different Geometries: A Review with Focus on Recent Development
}

\author{
Zeeshan A*, Pervaiz Z and Shehzad N \\ Department of Mathematics and Statistics, FBAS, International Islamic University, Islamabad, \\ Pakistan
}

*Corresponding author: Ahmed Zeeshan, Department of Mathematics and Statistics, FBAS, International Islamic University, Islamabad, Pakistan, Tel: +92519019759; Email: ahmad.

\section{Review Article \\ Volume 5 Issue 1}

Received Date: November 17, 2020

Published Date: January 18, 2021

DOI: $10.23880 /$ ppej-16000245 zeeshan@iiu.edu.pk

\section{Abstract}

In a thermo-dynamical system loss of energy takes the centre of attention. Laws of thermodynamics stated that energies of the system cannot be lost, but this energy could be engaged to perform useful work, or wastefully lost in form of rises in temperature of the system. It is eminent to control the factors which act in rising values of loss in energy. Nanofluids uses nanosized particles with very high thermal conductivity uniformly distributed in base fluids which increases the conductivity of the base fluid ridiculously. Nanofluid play a vital role in reducing the loss of energy and improve heat conduction. An effort has been made in this paper is to carry out an extensive review of the literature regarding Nanofluid in recent years. Some basic components and properties of nanofluids are deeply elaborated in this article. Preparation of nanofluids perform a very significant role in recent decades. The new advanced results in nanofluids helps the reader to clarify their concepts are argued using two major dynamical models.

Keywords: Nanofluid; Shape effects; Thermo-physical properties; Mathematical models

\section{Introduction}

Water and oil are most commonly used for heat transportation due to their fluidity, but low heat transfer character is an area of concern for such fluids. Whereas, the heat conductivity of the metals are much higher as compared to fluids, so it is of common interest to produce a class of fluid which can conduct heat or electricity like metals or their oxides. Nanofluids are by added nanosized particle with very high thermal conductivity in some base fluid [1-11]. Nowadays the technique involving both nanofluid and porous media finds considerable attention from many researchers and great demand from industry-based thermal systems. The logic behind it is that the surface area in contact with fluid in porous medium increases [12-16], while nanoparticles dispersed in nanofluid upsurge the effective thermal conductivity leading to the dramatic enhancement of the efficiency of typical industrial thermal systems. It is of vital importance to know the factor which reduces the thermal efficiency. According to laws of thermodynamics energy of the system remains to conserve, but can be converted into other forms for the utility [17-20]. More commonly we say all the energies of the system are spent in doing work or to augment the temperature of the body. Rise in use of nanofluids is one way to reduce the loss of energy. Increasing the heat transfer rate of heat transfer equipment is an ever-lasting topic in thermal engineering.

The motivation of this review paper is to emphasize on the researchers to pay attention to the basic understanding of heat transfer enhancement due to nanofluids and its components. The knowledge presented in this paper is of signifies in the engineering appliances which needs the efficient heat transfer heat transfer mediums. 


\section{Petroleum \& Petrochemical Engineering Journal}

\section{Nanofluids}

Industrial advancement in recent years boosted a need for efficient heat transfer and cooling process both at the micro or larger scale. Conventional fluids like air, water, or oils have smaller heat conductivity when compared with metallic solids.

The idea of adding solid particles in the liquid to enhancement the conductivity of liquids has been floated about a century ago when Maxwell established mathematical relations of the electrical conductivity of solid particles. But, these experiments and theoretical studies have been conducted with particles of size millimeter or micrometer. These particles tend to settle down quickly or form an aggregation. Also, they resist flow and cause a drop in pressure. To add to that a large number of particles are needed to improve the thermal conductivity of the fluid. Considering the adverse effects and limited advantage of the solid-liquid suspension these fluids can't hit the limelight.
With the advanced modern technology particles of a size, less than $100 \mathrm{~nm}$ are prepared of the metals and their oxides with better thermal conductivity, mechanical and magnetic performance base on the requirement of the system. These nanoparticles are uniformly dispersed in in Newtonian and non-Newtonian base fluids. These are stable suspend of nanoparticles with typical dimensions of the order of $10 \mathrm{~nm}$. The term "Nanofluid" was first used by Choi [21].

The theme to develop such fluids is to achieve the best thermal performance of the material which can be deformed or transported like fluids with a very small concentration of particles. It is important to learn the mechanism of enhancement as to know why a drastic increase in heat transfer character of nanofluid is observed. Figure 1 shows the increase in literature on nanofluid in last five year. Many scientists swiftly mounting nanofluids [22-46] proposed a different mechanism behind this adversity. Also, defines new mathematical models for the properties and flow behavior of nanofluids.

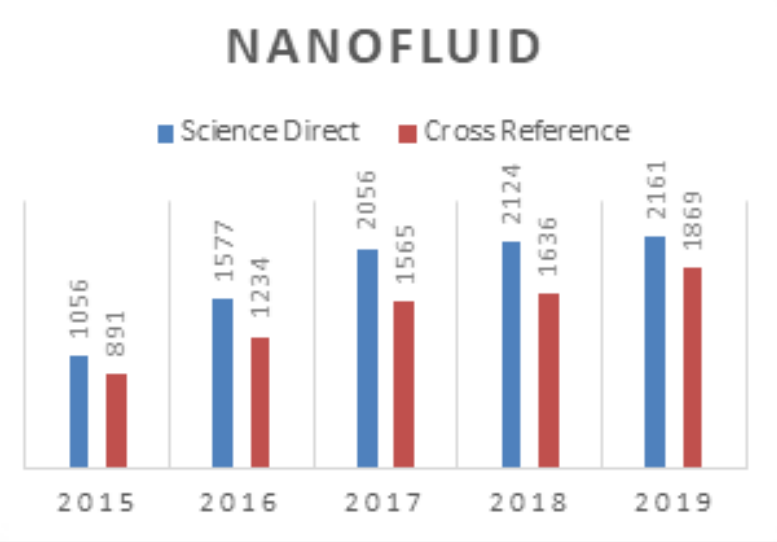

NANOFLUID

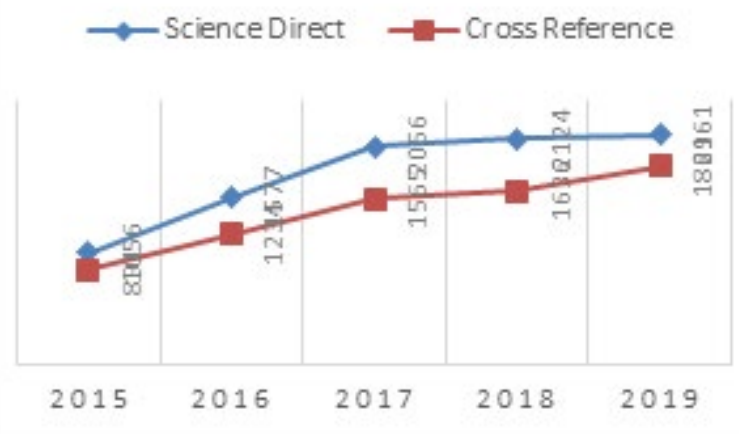

Figure 1: Search result on Science direct and Cross-reference metasearch with keyword "Nanofluid" in last five years.

\section{Components of Nanofluid}

Nanofluids are composed of Nanosized particles, base fluids and surfactants which forms a heterogeneous mixture.

Nanoparticles: Many metals and there oxides, Nitrides and carbides are used as nanoparticles. All possess properties to enhance thermal conductivity. Materials used for nanoparticles can be

- $\quad$ Metal (Al, Cu, Ag, Au etc).

- Metal carbides/Nitrides/oxides ( $\mathrm{SiC}, \mathrm{SiN}, \mathrm{AlN}, \mathrm{Al}_{2} \mathrm{O}_{3}, \mathrm{CuO}$ etc)

- Nonmetals (carbon nanotubes)

- Hybrid Nanofluid(includes multiple nanoparticles used in fixed proportions)
Base Fluids: Usually, the base fluid used for these nanoparticles as a carrier are fluids with low heat transfer rate or non-conductor of electricity (also called ferrofluids) in their pure form. Ideally, it is required to enhance such properties of the fluid. To generator a smart coolant or smart fuel in a weightless environment. Some example of base fluids are

- Water

- Ethylene

- Oils

- Biofluids

- Polymer solutions

Surfactants: Again comes the problem of stability of nanofluids i.e. agglomeration and clogging of nanofluids in 


\section{Petroleum \& Petrochemical Engineering Journal}

microchannels. Here, surfactant comes in play also known as dispersants. The surfactant is an economical way to increase the stability of nanofluid. The selection of the proper surfactant for given nanofluids is a key issue. Surfactant depends on the base fluids and nanoparticles used to prepare a nanofluid. Materials like can sometimes be used as the surfactant. Additionally, it is observed that with the inclusion of surfactants

- Sodium dodecyl benzoic sulfate

- Silica

\section{Preparation of Nanofluids}

Nanofluids are prepared using two processes known as Two-step method and single step method.

Two-step process: In a two-step, process nanoparticles are fabricated as dry powders using different chemical or physical processes. Then, the powder is uniformly dispersed in the base fluid and finally, high power magnetic field or shear mixing is applied to get a homogenous nanofluid. As powder manufacturing of these metallic particles is already a developed process and its techniques and manufacturing at commercial scale are already continuing in the industry this process is considered to be a cheaper process to get nanofluids at a commercial level. But, particles due to the sheer number and large surface area, they have a tendency to aggregate and provides unstable behaviour.

Single step process: Considering the difficulties, many techniques are employed to simultaneously make and disperse nanosized particles in base fluids in a so-called single step process. This process reduces the chances of agglomeration of nanoparticles by dispersing the particles as soon as developed and avoids process like dying and storing etc. But on the hand these methods cannot synthesize nanofluids for commercial scale and lifted the cost of such fluid to a very high level, alternative chemical processes are deployed for one step processes which are improving rapidly.

\section{Physical Properties of Nanofluids}

Almost a decades of extensive experimental and theoretical research on nanofluid couldn't still unveil all the hidden wonders of nanofluids. Also, a lack of agreement on mathematical and theoretical aspects of nanofluids and many possibilities of preparing nanofluids results in existence of a huge number of correlations defining physical and chemical properties of nanofluids. Factor like size, the shape of nanoparticles, base fluid, its $\mathrm{pH}$ value, surfactants, the thickness of the layer of surfactant and method for the production of nanofluids etc are the factor which affects the results and consequently make it hard to model the exact behaviour of any nanofluid.
Shape and size of Nanofluid: Many shapes and sizes of nanoparticles can be prepared using different techniques. The shapes and sizes affect the Nanofluid's thermal ability. Shapes like needle, platelets, brick, cylinder, rod and wire are more commonly used in literature other than traditional spherical particles. Yu and Choi [47] assumed ellipsoidal particles suspended in liquid with semi-axes of $\alpha, \beta$ and $\sigma$. The equation satisfying the solid ellipsoidal is

$$
\frac{x^{2}}{\alpha^{2}}+\frac{y^{2}}{\beta^{2}}+\frac{z^{2}}{\sigma^{2}}=1
$$

For a needle shape $\alpha>\beta=\sigma$, for disc $\alpha=\beta \gg \gamma$ and for sphere $\alpha=\beta=\sigma$. The Maxwell's macroscopic effective medium theory (EMT) [48] was extended by Hamilton and Crosser [49]. Some of the studies on the shape of the nanoparticles are described in Table 1. Size of nanoparticles an interesting relationship also. with increase an of size nanofluids conductivity decrease as the problems like clogging, aggerloments resurfaces. Many experimental studies show this results (See table [1]). Empirical shape factor $n$ was introduces as $n=3 / \psi$, here $\psi$ is the sphericity which can be calculated by dividing surface of the sphere and other surfaces.

Numerous investigators have since reported remarkable physical and mechanical properties of carbon. Carbon nanotubes illustrates a growing number of applications of carbon nanotubes (CNTs) in analytical chemistry. The structure of carbon nanotubes is first briefly summarized followed by a description of the characterization methods such as STM, TEM, neutron diffraction, X-ray diffraction, $\mathrm{X}$-ray photoelectron spectroscopy, infrared and Raman spectroscopy. Carbon nanotubes due to their specific atomic structure have interesting chemical and physical properties according to those of graphite and diamond. The characterization methods of carbon nanotubes which are most employed today.

From unique electronic properties and a thermal conductivity higher than diamond to mechanical properties where the stiffness, strength and resilience exceeds any current material, carbon nanotubes offer tremendous opportunities for the development of fundamentally new material systems. The mechanical properties of carbon nanotubes, combined with their low density, offer scope for the development of nanotube-reinforced composite materials. The natural convection boundary layer flow along a vertical cone with variable wall temperature under the presence of magneto-hydrodynamics is investigated. Vibration analysis of single-walled carbon nanotubes (SWCNTs) based on Love's thin shell theory has been investigated along with five sort of boundary conditions with 


\section{Petroleum \& Petrochemical Engineering Journal}

three different shapes.

The unique relationship between SWNT atomic structure and electronic properties, and the richness of structures observed in both purified and chemically etched nanotube samples are discussed. A more detailed picture of SWNT electronic band structure is developed and compared with experimental tunneling spectroscopy measurements. The experimental and theoretical investigations of localized structures, such as bends and ends in nanotubes, are presented. Last, quantum size effects in nanotubes with lengths approaching large molecules are discussed. The implications of these studies and important future directions are considered. Carbon nanotubes improved the ammonium biosensor response, linearity range of biosensor, detection limit of sensor, Multiwalled carbonnanotubes increased the response signal [50-60].

\begin{tabular}{|c|c|c|c|c|c|}
\hline 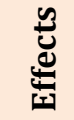 & Reference & $\begin{array}{l}\text { Particle } \\
\text { type }\end{array}$ & Particle sizes & Base fluid & Relevant information \\
\hline \multirow{10}{*}{ 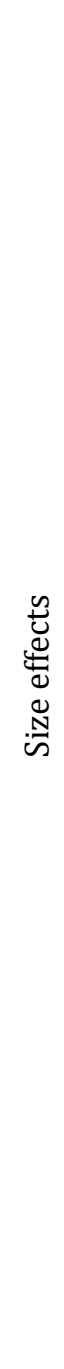 } & Masuda, et al. [61] & $\mathrm{Al} 203$ & $13 \mathrm{~nm}$ & Water & $\begin{array}{l}\text { Enhancement(Volume fraction): } 4.3 \% \\
\text { Enhancement(Thermal conductivity): } 33 \%\end{array}$ \\
\hline & Eastman, et al. [62] & $\mathrm{Al} 203$ & $33 \mathrm{~nm}$ & Water & $\begin{array}{l}\text { Enhancement(Volume fraction): } 4.3 \% \\
\text { Enhancement(Thermal conductivity): } 9 \%\end{array}$ \\
\hline & Lee, et al. [63] & $\mathrm{Al} 203$ & $38 \mathrm{~nm}$ & EG/Water & $\begin{array}{c}\text { Enhancement(Volume fraction): } 5.0 \% \text { (EG/ } \\
\text { water), } \\
\text { Enhancement(Thermal conductivity): } \\
18 \% \text { (EG) and } 12 \% \text { (Water) }\end{array}$ \\
\hline & Wang, et al. [64] & $\mathrm{Al} 203$ & $28 \mathrm{~nm}$ & $\begin{array}{c}\text { EG } \\
\text { Water }\end{array}$ & $\begin{array}{c}\text { Enhancement(Volume fraction): } 5 \% \\
\text { Enhancement(Thermal conductivity): } \\
17 \%(\mathrm{EG}) \\
\text { and } 14 \% \text { (Water) }\end{array}$ \\
\hline & Xie, et al. $[65,66]$ & $\mathrm{Al} 203$ & $60.4 \mathrm{~nm}$ & $\begin{array}{l}\text { Water } \\
\text { EG }\end{array}$ & $\begin{array}{c}\text { Enhancement(Volume fraction): 5\%(EG/ } \\
\text { Water) } \\
\text { Enhancement(Thermal conductivity): } \\
22 \% \text { (Water) } \\
\text { and 29\%(EG) }\end{array}$ \\
\hline & Das, et al. [67] & Al203 & $38 \mathrm{~nm}$ & Water & $\begin{array}{l}\text { Enhancement(Volume fraction): } 4 \% \\
\text { Enhancement(Thermal conductivity): } 8 \%\end{array}$ \\
\hline & Putra, et al. [68] & $\mathrm{Al} 203$ & $131 \mathrm{~nm}$ & Water & $\begin{array}{l}\text { Enhancement(Volume fraction): } 4 \% \\
\text { Enhancement(Thermal conductivity): } 25 \%\end{array}$ \\
\hline & Wen and Ding [69] & $\mathrm{Al} 203$ & $37-56 \mathrm{~nm}$ & Water & $\begin{array}{l}\text { Enhancement(Volume fraction): } 1.6 \% \\
\text { Enhancement(Thermal conductivity): } 10 \%\end{array}$ \\
\hline & Nara, et al. [70] & $\mathrm{Al} 203$ & $40 \mathrm{~nm}$ & $\begin{array}{l}\text { Water } \\
\text { EG }\end{array}$ & $\begin{array}{c}\text { Enhancement(Volume fraction): } \\
\text { 0.5\%(Water/EG) } \\
\text { Enhancement(Thermal conductivity): } \\
\text { 34\%(Water), } 5 \% \text { (EG) }\end{array}$ \\
\hline & Chon, et al. [71] & $\mathrm{Al} 203$ & $11,47,150 \mathrm{~nm}$ & Water & $\mu_{150 \mathrm{~nm}} \leq \mu_{47 \mathrm{~nm}} \leq \mu_{11 \mathrm{~nm}}$ \\
\hline
\end{tabular}




\section{Petroleum \& Petrochemical Engineering Journal}

\begin{tabular}{|c|c|c|c|c|c|}
\hline & Li and Peterson [72] & $\mathrm{Al} 203$ & $36,47 \mathrm{~nm}$ & Water & $\begin{array}{c}\text { Enhancement(Volume fraction): } 6 \% \\
\text { Enhancement(Thermal conductivity): } 28 \%\end{array}$ \\
\hline & Krishnamurthy, et al. [73] & $\mathrm{Al} 203$ & $20 \mathrm{~nm}$ & Water & $\begin{array}{l}\text { Enhancement(Volume fraction): } 1 \% \\
\text { Enhancement(Thermal conductivity): } 16 \%\end{array}$ \\
\hline & Zhang, et al. [74] & $\mathrm{Al} 203$ & $20 \mathrm{~nm}$ & Water & $\begin{array}{l}\text { Enhancement(Volume fraction):5\% } \\
\text { Enhancement(Thermal conductivity): } 15 \%\end{array}$ \\
\hline & He, et al. [75] & $\mathrm{TiO3}$ & $95,145,210 \mathrm{~nm}$ & Water & $\mu_{210 \mathrm{~nm}} \leq \mu_{145 \mathrm{~nm}} \leq \mu_{95 \mathrm{~nm}}$ \\
\hline & Li and Peterson [76] & $\mathrm{Al} 2 \mathrm{O} 3$ & $36,47 \mathrm{~nm}$ & Water & $\mu_{47 \mathrm{~nm}} \leq \mu_{36 \mathrm{~nm}}$ \\
\hline & Anoop, et al. [77] & $\mathrm{Al} 203$ & $45,150 \mathrm{~nm}$ & Water & $\mu_{150 \mathrm{~nm}} \leq \mu_{45 \mathrm{~nm}}$ \\
\hline & Vajjha and Das [78] & $\mathrm{ZnO}$ & $29,77 \mathrm{~nm}$ & EG-Water & $\mu_{77 \mathrm{~nm}} \leq \mu_{29 \mathrm{~nm}}$ \\
\hline & Patel, et al. [79] & $\mathrm{Al} 203$ & $11,45,150 \mathrm{~nm}$ & $\begin{array}{l}\text { EG, oil, } \\
\text { water, }\end{array}$ & $\mu_{150 \mathrm{~nm}} \leq \mu_{45 \mathrm{~nm}} \leq \mu_{11 \mathrm{~nm}}$ \\
\hline & Teng, et al. [80] & $\mathrm{Al} 203$ & $20,50,100 \mathrm{~nm}$ & Water & $\mu_{100 \mathrm{~nm}} \leq \mu_{50 \mathrm{~nm}} \leq \mu_{20 \mathrm{~nm}}$ \\
\hline 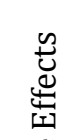 & Akbulut, et al. [81] & $\mathrm{ZnS}$ & $\begin{array}{l}\text { Sphere, rod, and } \\
\text { wires }\end{array}$ & & $\begin{array}{c}\text { The increased steric contribution of the } \\
\text { nanostructures to the overall surface } \\
\text { interaction }\end{array}$ \\
\hline$\frac{0}{\pi}$ & $\begin{array}{l}\text { Timofeeva, } \\
\text { et al. [82] }\end{array}$ & Al203 & $\begin{array}{l}\text { Platelet, blade, } \\
\text { cylinder, } \\
\text { and brick }\end{array}$ & EG/water & $\begin{array}{l}\text { Elongated particles and agglomerates } \\
\text { resulted in higher viscosity at the } \\
\text { same volume fraction due to } \\
\text { structural limitation of rotational } \\
\text { and transitional Brownian motions }\end{array}$ \\
\hline & Cui, et al. [83] & $\mathrm{Cu}$ & $\begin{array}{l}\text { Sphere and } \\
\text { cylinder }\end{array}$ & & $\begin{array}{c}\text { Enhancement of } \\
\text { Sphere(Viscosity): } 14.8 \% \\
\text { Enhancement of } \\
\text { Cylinder(Thermal conductivity): } 20.31 \% \\
\text { Enhanced micro-convection of the } \\
\text { cylindrical shape from rotational } \\
\text { motion, which increased thermal } \\
\text { conductivity }\end{array}$ \\
\hline & Ghosh and Pabi [84] & $\mathrm{Cu}$ & Cylinder & & $\begin{array}{c}\text { Increased contact area with increase } \\
\text { of aspect ratio of nanoparticle } \\
\text { induced higher rate of heat transfer } \\
\text { during the collision }\end{array}$ \\
\hline & $\begin{array}{l}\text { Pilkington and } \\
\text { Briscoe [85] }\end{array}$ & $\mathrm{N} / \mathrm{A}$ & $\mathrm{N} / \mathrm{A}$ & $\mathrm{N} / \mathrm{A}$ & $\begin{array}{l}\text { Aspect ratio of the nanostructures } \\
\text { has an effect on the equilibrium } \\
\text { forces mediated by nanofluids that } \\
\text { can affect the viscosity of nanofluids }\end{array}$ \\
\hline
\end{tabular}




\begin{tabular}{|c|c|c|c|c|c|}
\hline Ooi and Popov [86] & Cu & $\begin{array}{c}\text { Sphere and } \\
\text { spheroid }\end{array}$ & $\begin{array}{c}\text { Enhancement(Viscosity): } \\
40-603 \%\end{array}$ \\
Enhancement(Thermal conductivity): \\
$\begin{array}{c}32-151 \% \\
\text { Estimated by the HeC model and the } \\
\text { Mueller et al.'s model }\end{array}$ \\
\hline Ferrouillat, et al. [87] & SiO2 & $\begin{array}{c}\text { Sphere and } \\
\text { banana } \\
\text { Polygonal and } \\
\text { rod }\end{array}$ & Water & $\begin{array}{c}\text { Following the Timofeeva et al.'s } \\
\text { analysis (2009). } \\
\text { Enhancement is lower than predicted } \\
\text { by the HeC model. } \\
\text { Banana shape nanoparticles have } \\
\text { larger surface area in contact with } \\
\text { stabilizing chemicals than that of } \\
\text { spherical ones }\end{array}$ \\
\hline
\end{tabular}

Table 1: Size and Shape effects of nanoparticles in nanofluids.

Density of Nanofluid: Density is defined as mass per unit volume. Vajjaha and Das [88] perform a number of experiments with ethylene glycol and water base fluids. The relationship is defined as

$$
\rho_{n f}=\varphi \rho_{p}+(1-\varphi) \rho_{f}
$$

The mathematical equation for the density of the twophase mixture of solid in a liquid is adopted by Pak and Cho [89] and verify the result for $\mathrm{Al}_{2} \mathrm{O}_{3}$.

Specific Heat capacity: Mathematically, specific heat capacity at constant pressure is the amount of heat required to raise the temperature of the $1 \mathrm{Kg}$ fluid through $1 \mathrm{~K}$. A correlation for the specific of nanofluid is calculated by Pak and Cho [89] for $\mathrm{Al}_{2} \mathrm{O}_{3}$-water nanofluid is

$$
c_{n f}=\varphi c_{p}+(1-\varphi) c_{f}
$$

Here, $c_{f}$ is calculated ASHRAE Handbook [90] as

$$
c_{f}=4.2483 T+1882.4 \text { for } 293 \mathrm{~K} \leq \mathrm{T} \leq 363 \mathrm{~K}(4)
$$

The results were improved by Buongiorno [91] by including density in it. The expression becomes

$$
(\rho c)_{n f}=\varphi(\rho c)_{S}+(1-\varphi)(\rho c)_{f}
$$

Viscosity: The viscosity of the fluid with the spherical particle is calculated by Einstein [92] as

$$
\frac{\mu_{e f f}}{\mu_{f}}=1+2.5 \phi(6)
$$

It is established that no theoretical model as yet can explain the viscosity of nanofluid completely but there are numerous correlations available defining the viscosity for some restricted conditions. The viscosity of Nanofluids depends mainly on the concentration of nanoparticles, but also, the temperature of the fluid, shape, size and density of the particles. Many theoretical and experimental investigations lead to different viscosities in different scenarios and

\begin{tabular}{|c|c|c|c|c|}
\hline$\frac{\bar{d}}{2}$ & Reference & 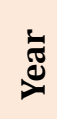 & Correlation & Relevant information \\
\hline & Saito [98] & 유 & $\frac{\mu_{e f f}}{\mu_{f}}=1+\frac{2.5}{(1-\phi)} \phi$ & Spherical rigid particles \\
\hline & Brinkman [99] & ํㅡㅁ & $\frac{\mu_{e f f}}{\mu_{f}}=\frac{1}{(1-\phi)^{2.5}}$ & $\begin{array}{l}\text { Brownian motion } \\
\text { Very small particles } \\
\text { Spherical particles }\end{array}$ \\
\hline
\end{tabular}
improvement is overseen in the current models. Many review papers show a comprehensive review of effective viscosity of nanofluids [93-97]. Table 2 shows some of the theoretical and experimental models for the viscosity of nanofluids. 
Petroleum \& Petrochemical Engineering Journal

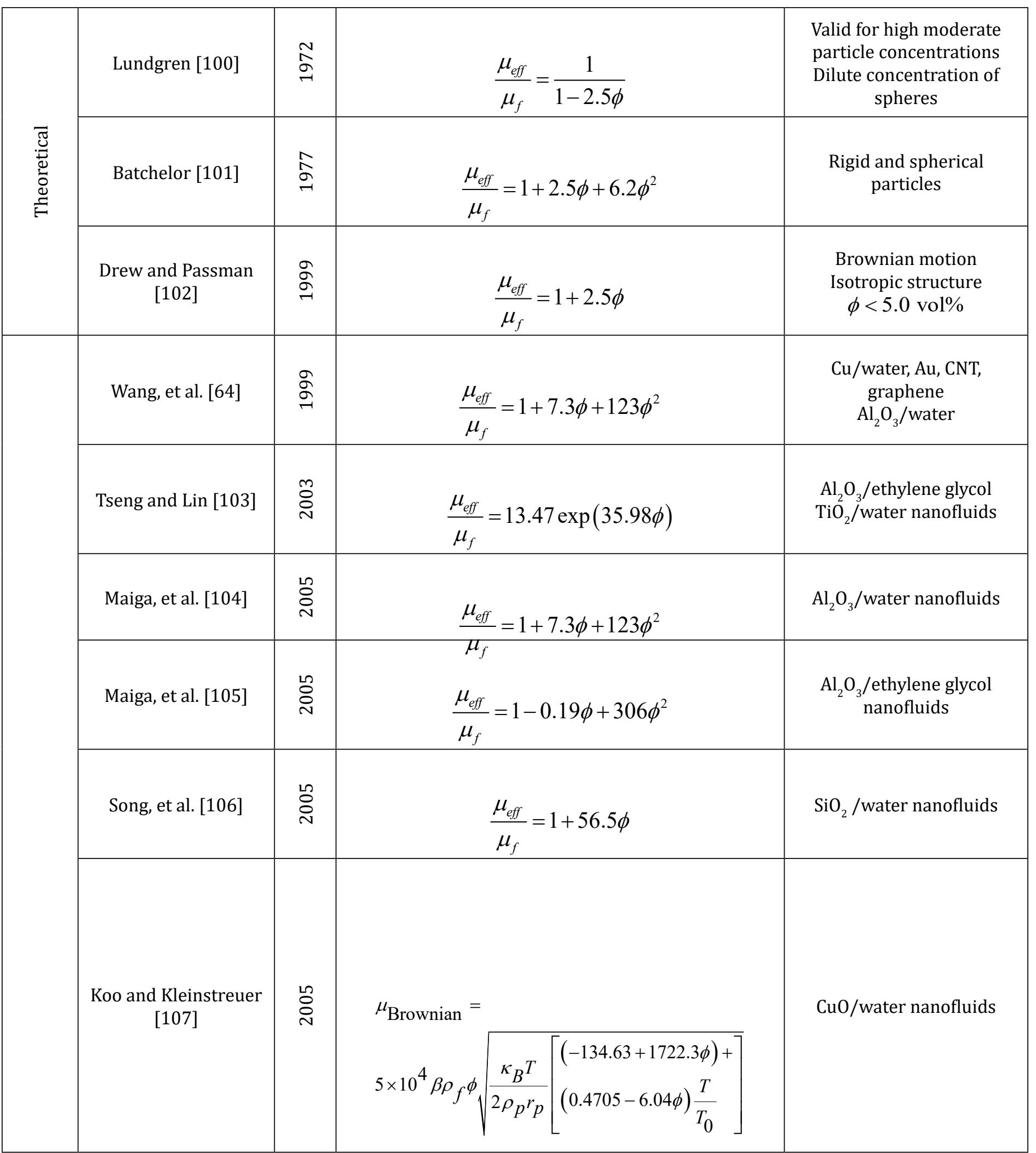




\begin{tabular}{|c|c|c|c|c|}
\hline & Kulkarni, et al. [108] & ஜ̊ & $\begin{array}{c}\ln \mu_{e f f}=A\left(\frac{1}{T}\right)-B, \\
A=20587 \phi^{2}+15857 \phi+1078.3 \\
B=-107.12 \phi^{2}+53.54 \phi+2.8715\end{array}$ & $\begin{array}{l}0.05 \leq \phi \leq 0.15 \\
d_{p}=29 \mathrm{~nm} \text {-water } \\
278 \leq \mathrm{T} \leq 323 \mathrm{~K} \\
\text { Shear rate }=1001 / \mathrm{s}\end{array}$ \\
\hline & Buongiorno [91] & ¿̊ & $\begin{array}{l}\frac{\mu_{e f f}}{\mu_{f}}=1+5.45 \phi+108.2 \phi^{2} \\
\frac{\mu_{e f f}}{\mu_{f}}=1+39.11 \phi+533.9 \phi^{2}\end{array}$ & $\begin{array}{l}\mathrm{TiO}_{2} / \text { water nanofluids } \\
\mathrm{Al}_{2} \mathrm{O}_{3} / \text { water nanofluids }\end{array}$ \\
\hline 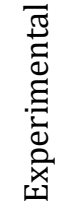 & Chen, et al. [109] & ڤ̊̀ & $\frac{\mu_{e f f}}{\mu_{f}}=1+10.6 \phi+112.36 \phi^{2}$ & $\begin{array}{c}\mathrm{TiO}_{2} / \text { ethylene glycol } \\
\text { nanofluids }\end{array}$ \\
\hline & Nguyen, et al. [110] & $\stackrel{\hat{\sigma}}{\circ}$ & $\begin{array}{l}\frac{\mu_{\text {eff }}}{\mu_{f}}=0.904 \exp (0.1483 \phi) \mathrm{d}_{p}=47 \mathrm{~nm} \\
\frac{\mu_{\text {eff }}}{\mu_{f}}=1+0.025 \phi+0.015 \phi^{2} \mathrm{~d}_{p}=36 \mathrm{~nm} \\
\frac{\mu_{\text {eff }}}{\mu_{f}}=1.475-0.319 \phi+0.051 \phi^{2}+0.009 \phi^{3} \\
\mathrm{~d}_{p}=26 \mathrm{~nm}\end{array}$ & $\begin{array}{l}\mathrm{Al}_{2} \mathrm{O}_{3} / \text { water nanofluids } \\
\mathrm{CuO} / \text { water nanofluids }\end{array}$ \\
\hline
\end{tabular}




\begin{tabular}{|c|c|c|c|}
\hline Namburu, et al. [111] & 仓े & $\begin{array}{l}\log \left(\mu_{\text {eff }}\right)=A \exp (-B T) \\
A=1.8375 \phi^{2}-29.643 \phi+165.56 \\
B=4 \times 10^{-6} \phi^{2}-0.001 \phi+0.0186\end{array}$ & $\mathrm{CuO} /(60: 40)$ \\
\hline Grag, et al. [112] & $\stackrel{\infty}{\stackrel{\circ}{\circ}}$ & $\frac{\mu_{e f f}}{\mu_{f}}=1+11 \phi$ & $\begin{array}{l}\text { EG/water nanofluids } \\
\mathrm{Cu} / \text { ethylene glycol } \\
\text { nanofluids }\end{array}$ \\
\hline Masoumi, et al. [113] & 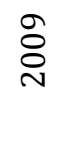 & $\mu_{e f f}=\mu_{f}+\frac{\rho_{p} v_{B} d_{p}^{2}}{72 C \delta}, \delta=\sqrt[3]{\frac{\pi}{6 \phi} d_{p}}$ & $\mathrm{Al}_{2} \mathrm{O}_{3} /$ water nanofluids \\
\hline $\begin{array}{l}\text { Duangthongsuand } \\
\text { Wongwises [114] }\end{array}$ & 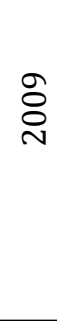 & $\begin{array}{c}\frac{\mu_{e f f}}{\mu_{f}}=a+b \phi+c \phi^{2} \\
a=1.0226, b=0.0477, c=-0.0112 \text { for } T=15^{\circ} \mathrm{C} \\
a=1.0130, b=0.0920, c=-0.0177 \text { for } T=25^{\circ} \mathrm{C} \\
a=1.0180, b=0.1120, c=-0.0177 \text { for } T=35^{\circ} \mathrm{C}\end{array}$ & $\mathrm{TiO}_{2} /$ water nanofluids \\
\hline $\begin{array}{c}\text { Chandrasekar, et al. } \\
\text { [115] }\end{array}$ & $\stackrel{\circ}{\stackrel{\circ}{\circ}}$ & $\begin{array}{l}\frac{\mu_{e f f}}{\mu_{f}}=1+b\left(\frac{\phi}{1+\phi}\right)^{n} \\
b=1631, n=2.8\end{array}$ & $\mathrm{Al}_{2} \mathrm{O}_{3} /$ water nanofluids \\
\hline
\end{tabular}




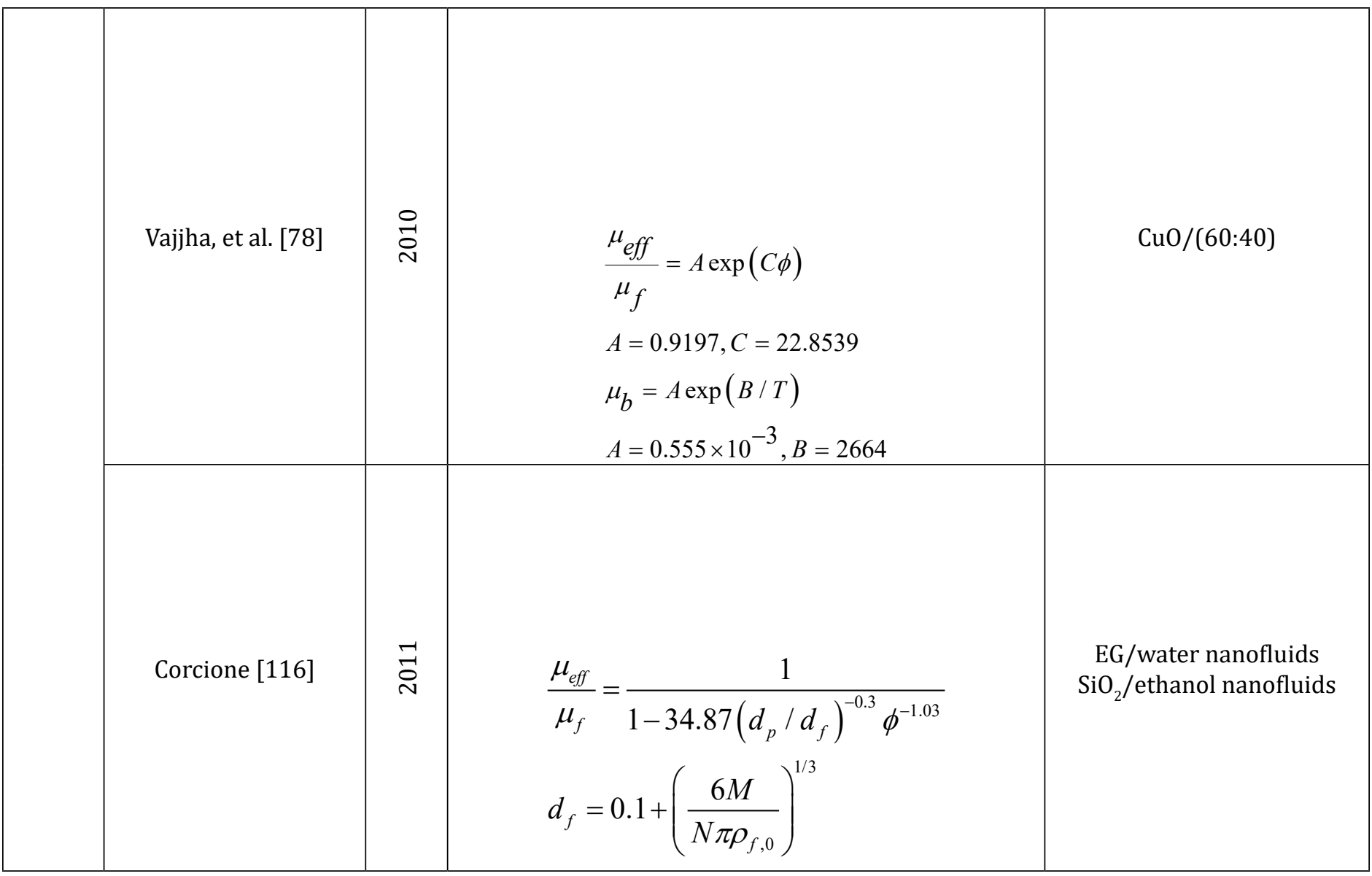

Table 2: Summary of the studies on the theoretical and experimental models effective viscosity of nanofluids.

Thermal conductivity: Like viscosity, thermal conductivity also has no reliable model that effectively define all fluids in all conditions many correlations both theoretical and experimental are available in literature defining thermal conductivity (table 3). It is seen through experiments that thermal conductivity enhances the presence of nano-sized particles in fluid drastically hence an increase in thermal conductivity of the fluid is evident. Thermal conductivity shows its variation with change in the density of both fluid and particles, shape, size, concentration, heat conductivity etc. Maxwell [48] defined conductivity base on EMT for spherical particles as

$$
k_{\text {eff }}=\frac{(k p+2 k f)+2(k p-k f) \varphi}{(k p+2 k f)-(k p-k f) \varphi}
$$

Hamilton and cross [49] incorporated shape factor and defines thermal conductivity as

$$
k_{\text {eff }}=\frac{(k p+(n-1) k f)+(n-1)(k p-k f) \varphi}{(k p+(n-1) k f)-(k p-k f) \varphi}
$$

Vajjha, et al. [78] displays effects of density

$$
\frac{k_{e f f}}{k_{f}}=\frac{k_{p}+2 k_{f}-2 \phi\left(k_{f}-k_{p}\right)}{k_{p}+2 k_{f}+\phi\left(k_{f}-k_{p}\right)}+5 \times 10^{4} \beta \rho_{p} c p \sqrt{\frac{\kappa_{B} T}{\rho_{p} D}} f(T, \phi)
$$

Corcione [116] defined the dependence of thermal conductivity on the fluid temperature.

$$
\frac{k_{e f f}}{k_{f}}=1+4.4 \operatorname{Re}^{0.4} \operatorname{Pr}^{0.66}\left(\frac{T}{T_{f r}}\right)^{10}\left(\frac{k_{p}}{k_{f}}\right)^{0.03} \phi^{0.66}
$$

Some review papers display effective viscosity and thermal conductivity recently [93-97].

Experimental and theoretical models are developed some of such models are shown in Table 3. 


\begin{tabular}{|c|c|c|}
\hline Reference & Correlation & Relevant information \\
\hline Bruggemann [117] & $\begin{array}{l}\frac{k_{e f f}}{k_{f}}=\frac{1}{4}\left[(3 \phi-1) \frac{k_{p}}{k_{f}}+(2-3 \phi)\right]+\frac{k_{f}}{4} \sqrt{\Delta} \\
\Delta=\left[\begin{array}{l}(3 \phi-1)^{2}\left(\frac{k_{p}}{k_{f}}\right)^{2}+(2-3 \phi)^{2}+ \\
2\left(2+9 \phi-9 \phi^{2}\right) \frac{k_{p}}{k_{f}}\end{array}\right]\end{array}$ & $\begin{array}{c}\text { Darticle Spherical } \\
\text { ppherical particles } \\
\text { papplicable to high concentrations }\end{array}$ \\
\hline Wasp [118] & $\frac{k_{e f f}}{k_{f}}=\frac{k_{p}+2 k_{f}-2 \phi\left(k_{f}-k_{p}\right)}{k_{p}+2 k_{f}+\phi\left(k_{f}-k_{p}\right)}$ & $\begin{array}{c}\text { Spherical and non-spherical } \\
\text { particles, } \\
\text { Micro-dimensions } \\
\text { Various particle shapes, } \\
\text { Hamilton and Crosser's model } \\
\text { with } n=3 \cdot \\
\text { Shape factor is unity. }\end{array}$ \\
\hline Davis [119] & $\frac{k_{e f f}}{k_{f}}=1+\frac{3(k-1)}{(k-2)-\phi(k-1)}\left[\phi+f(k) \phi^{2}+O \phi^{3}\right]$ & $\begin{array}{l}f(k)=2.5 \text { for } k=10 \\
f(k)=0.5 \text { for } k=\infty\end{array}$ \\
\hline Lu and Lin [120] & $\frac{k_{e f f}}{k_{f}}=1+a \phi+b \phi^{2}$ & $\begin{array}{l}\text { Spherical and non-spherical } \\
\text { particles For } \\
\qquad \begin{aligned} k & =10: \\
a & =2.25, b=2.27 \\
k & =\infty: \\
a & =3.00, b=4.51\end{aligned}\end{array}$ \\
\hline
\end{tabular}




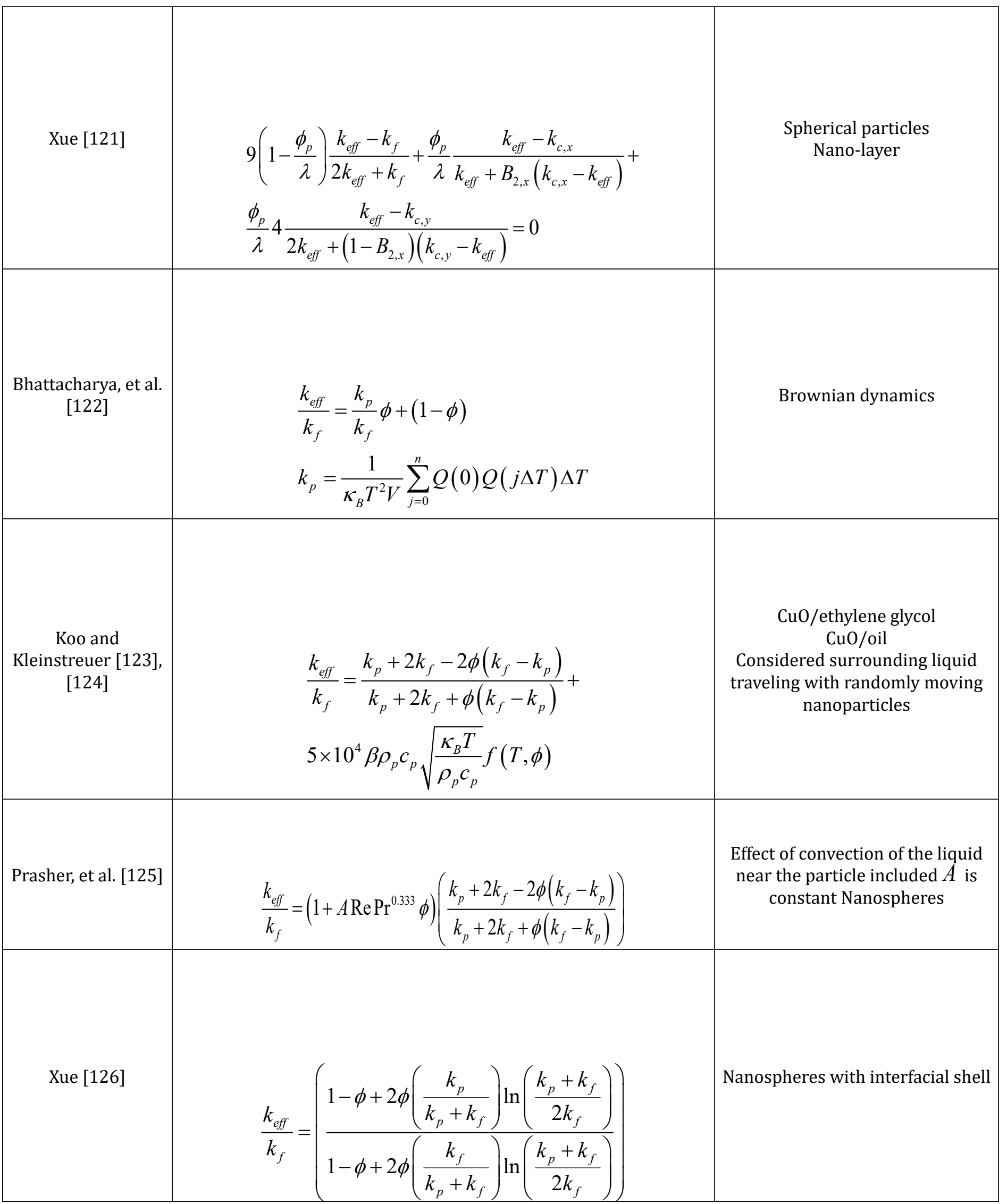




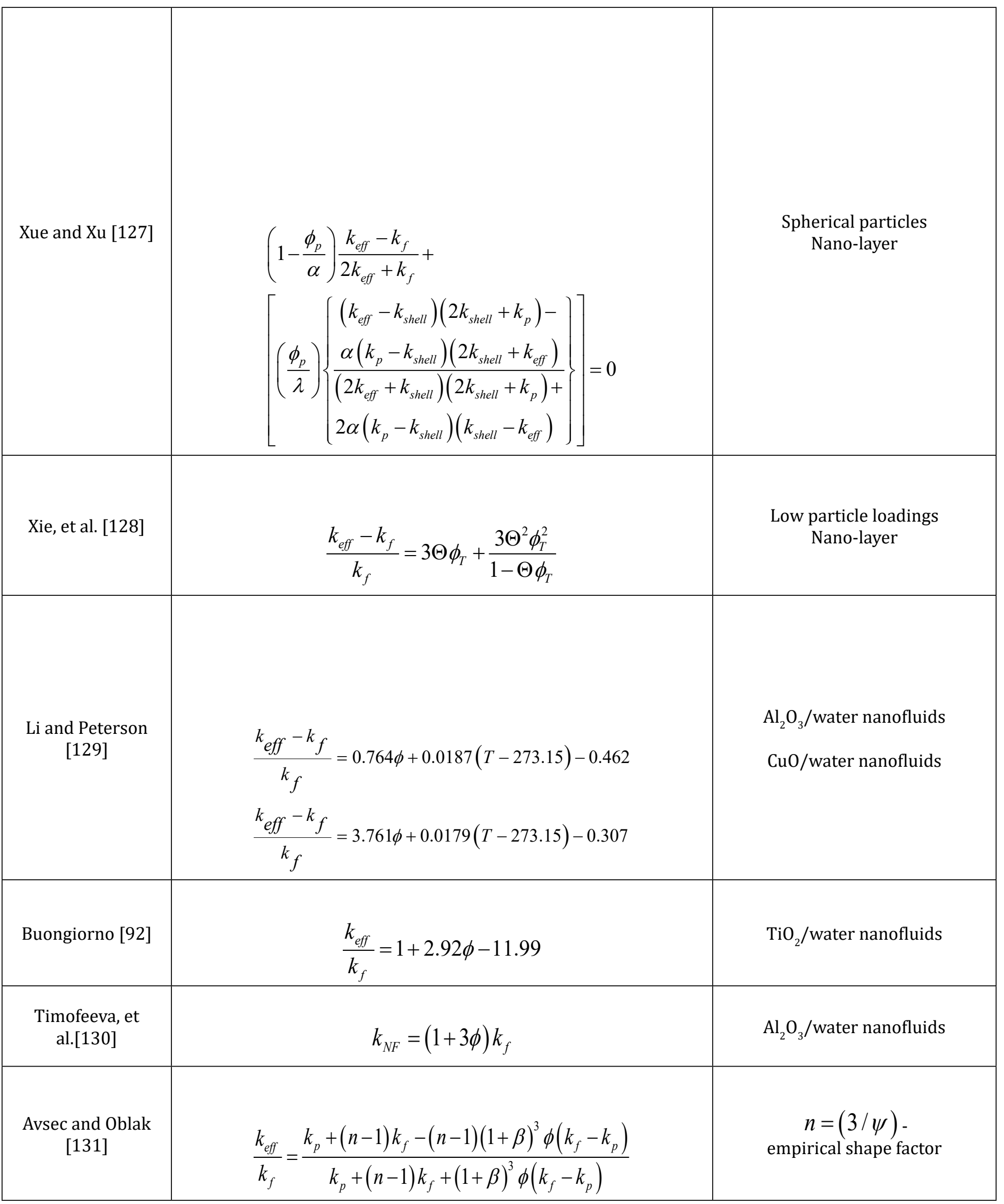




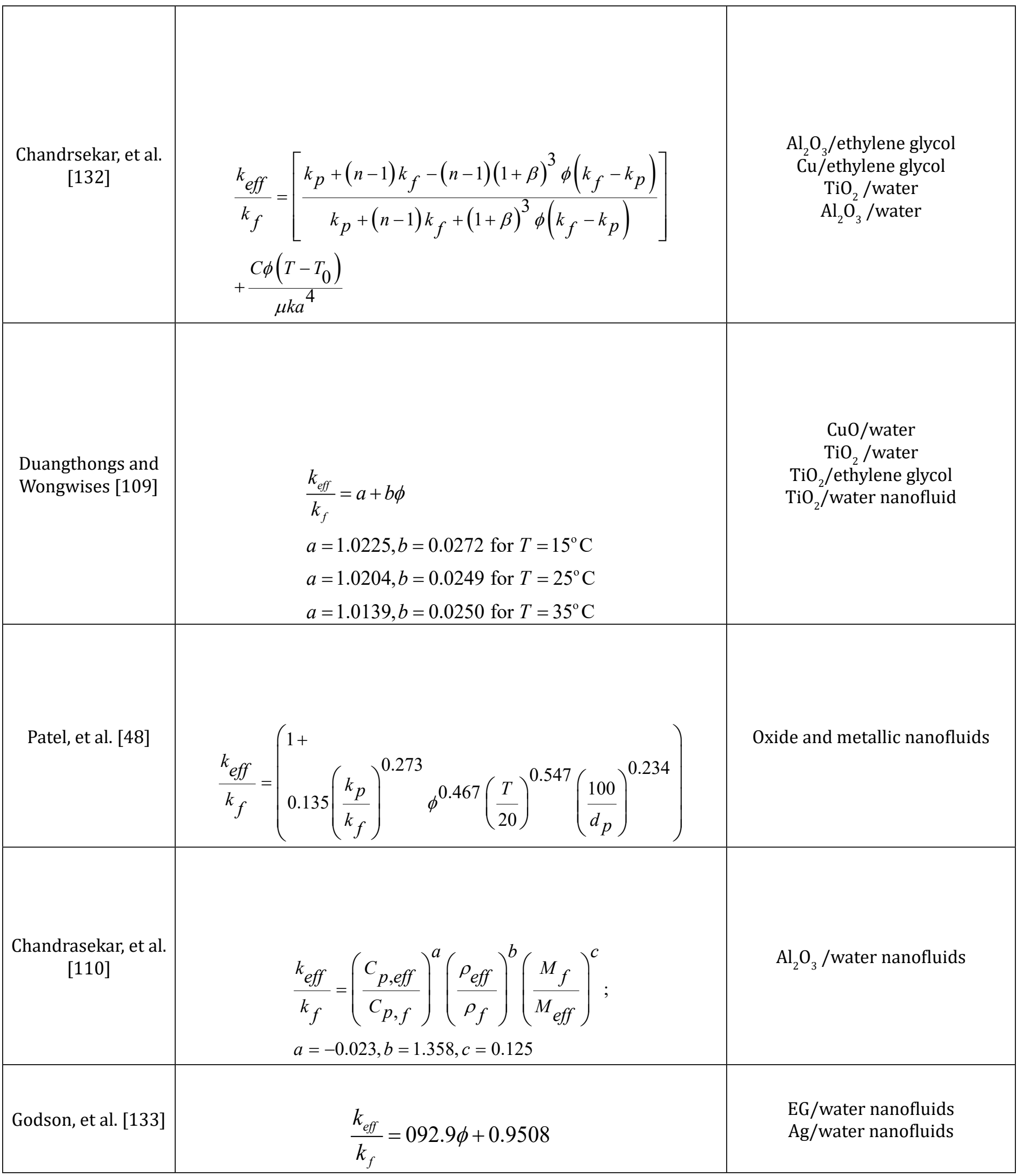

Table 3: Models for thermal conductivity. 


\section{Petroleum \& Petrochemical Engineering Journal}

\section{Nanofluid Dynamical Models}

Masuda observed the thermal enhancement due to the nanoparticle in 1993 and Choi tossed the term nanofluid in 1994. But it was not before 2006 that a mathematical model for the flow of nanofluids is described. Nanofluids have higher thermal conductivity and heat transfer coefficients than their base fluids. The change in viscosity and thermal conductivity is of the fluid effects its dynamics. Two mathematical models are developed to accurately describe the flow patterns and heat transfer effects are so-called Buongiorno's model and Tiwari-Das model.

Buongiorno's model: In 2006, Buongiorno [91] observed from the results of that these fluids shows an abnormal increase in thermal conductivity, viscosity and heat transfer rate coefficient. It is due to the nanofluid property of the Thermophoresis and temperature gradient. To validate they checked the relative motion of particles for inertial slip, Brownian diffusion, thermophoresis, diffusiophoresis, Magnus effect, fluid drainage, and gravity. It emerges that only Brownian diffusion and thermophoresis affects the flow drastically.

To obtain the conservation equations of Nanofluids, consider the incompressible flow of nanofluid. It is assumed that both nanoparticle and base fluid is chemically inert hence no chemical reaction can take place. Also, it is assumed that the concentration of the particles is small. Nanoparticles and base fluid are assumed to be in equilibrium. Four equations describe the flows i.e. two continuity equations (for base fluid and for nanoparticles) and the single equation for both momentum and heat transfer.

The continuity equation for fluid can be

$$
\nabla . \mathrm{V}=0(11)
$$

Here, $\mathrm{V}$ is the velocity of the fluid. For the particle, if J is diffusion mass flux of the nanoparticle w.r.t. fluid velocity, then it can be written as the sum of Brownian motion and thermophoresis if no external force is applied

$$
-\frac{1}{\rho} \nabla \cdot J=\frac{\partial \varphi}{\partial t}+V \cdot \nabla \varphi=\nabla \cdot\left[D_{B} \nabla \varphi+D_{B} \frac{\nabla T}{T}\right]
$$

Where $\varphi$ is the concentration of nanoparticles, $\mathrm{D}_{\mathrm{B}}$ and $\mathrm{D}_{\mathrm{T}}$ are due to slip velocity of particles cause by Brownian motion and thermoprosis. The momentum equation for nanofluids with non-external force or diffusion term is defined with as

$$
\rho\left[\frac{\partial V}{\partial t}+V . \nabla V\right]=-\nabla P-\nabla . \tau
$$

$\mathbf{P}$ is the pressure and is the stress tensor.

The energy equations for nanofluids

$$
\rho c\left[\frac{\partial T}{\partial t}+V . \nabla T\right]=-\nabla \cdot q+h_{p} \nabla . J
$$

Neglecting radiative heat transfer, q can be calculated as the sum of the conduction heat flux and the heat flux due to nanoparticle diffusion

$$
q=-k \nabla T+h_{p} J
$$

$\mathrm{c}$ is heat capacity, hp is specific enthalpy.

Tiwari and Das' Model: In this model [134], flow is assumed to laminar and incompressible. The model uses continuity, momentum and energy equations for a Newtonian fluid. If radiation heat transfer and other external forces are negligible and assuming constant thermal properties, the continuity, momentum and heat equation defined by the law of conservation of mass, momentum and energy respectively form the full flow model are defined as

For Continuity equation

$$
\nabla \cdot \mathrm{V}=0(16)
$$

For momentum equation

$$
\rho_{n f}\left[\frac{\partial V}{\partial t}+V . \nabla V\right]=-\nabla P-\nabla . \tau
$$

The equation is traditional Navier-stokes equation. With is defined usually for Newtonian base fluid as $\tau=\mu_{n f}\left(\nabla \cdot V+\nabla \cdot V^{\prime}\right) \cdot \mu_{n f} \quad$ varies drastically with the concentration of nano particle(see Table. 2).

The energy equations for nanofluids

$$
\rho_{n f} C_{n f}\left[\frac{\partial T}{\partial t}+V . \nabla T\right]=-\nabla \cdot q^{\prime}
$$

Neglecting radiative heat transfer, $\mathbf{q}^{\prime}$ can be calculated as

$$
\operatorname{Req}=-k_{n f} \nabla T
$$

\section{Conclusion}

A number of essential conclusions and recommendations can be carried out regarding current knowledge and future research

1. Nanofluids shows a big revolution in recent decades that are fully elaborated in our literature. Many techniques were used in order to enhance the energy gain or loss for example in industry, in chemical reactors, in cooling of machine's engine, in refrigerator, in electrical, in solar energy, in electronic chips and also in heavy machineries 
used in defense purpose.

2. Many significant results are introduced in recent decades about thermo-dynamical system. Reader can easily enhance their concepts of loss of energy in any system and then it is further used in various energy sectors.

3. Many advanced theoretical and experimental results that are discussed to helps the reader to clarify their results with two dynamical models.

4. Models of thermal conductivity, Theoretical and experimental models of effective viscosity, Size and Shape effects of nanoparticles in nanofluids are increasing rapidly in current research work. Which helps the reader to easily use these models in their research.

\section{Nomenclature}

\begin{tabular}{|c|c|}
\hline $\mathrm{Cu}$ & Copper \\
\hline $\mathrm{Ag}$ & Silver \\
\hline $\mathrm{Au}$ & Gold \\
\hline $\mathrm{SiC}$ & Silicon Carbide \\
\hline $\mathrm{SiN}$ & Silicon Nitride \\
\hline AIN & Aluminum Nitride \\
\hline $\mathrm{AL}_{2} \mathrm{O}_{3}$ & Aluminum Oxide \\
\hline $\mathrm{CuO}$ & Copper Oxide \\
\hline $\mathrm{TiO3}$ & Titanate \\
\hline $\mathrm{ZnO}$ & Zinc Oxide \\
\hline $\mathrm{ZnS}$ & Zinc Sulfide \\
\hline $\mathrm{HeC}$ & Hydroxyethyl Cellulose \\
\hline $\mathrm{SiO}_{2}$ & Silicon Dioxide \\
\hline EG & Ethylene Glycol \\
\hline$\alpha, \beta$ and $\sigma$ & Semi-axes \\
\hline $\mathrm{X}, \mathrm{y}$ and $\mathrm{z}$ & Major axes \\
\hline $\mathrm{n}$ & Empirical shape factor \\
\hline$\psi$ & Sphericity \\
\hline $\mathrm{nm}$ & Nanometer \\
\hline$\mu$ & Viscosity \\
\hline$\rho_{f}$ & Fluid Density \\
\hline$\varphi$ & Nanoparticle volume fraction \\
\hline$\rho_{n f}$ & Nanofluid Density \\
\hline$c_{f}$ & Specific heat of fluid \\
\hline$c_{p}$ & Specific heat of particle \\
\hline
\end{tabular}

\begin{tabular}{|c|c|}
\hline$c_{n f}$ & Specific heat of nanofluid \\
\hline$(\rho c)_{n f}$ & Heat capacity of the nanofluid \\
\hline$(\rho c)_{f}$ & Heat capacity of the fluid \\
\hline$(\rho c)_{p}$ & Heat capacity of the nanoparticle \\
\hline$\mu_{\text {eff }}$ & Effective Viscosity \\
\hline$\mu_{f}$ & Fluid Viscosity \\
\hline$\kappa_{B}$ & $\begin{array}{l}\text { Excess thermal-conductivity enhancement } \\
\text { coefficient }\end{array}$ \\
\hline$\rho_{p}$ & Nanoparticle Density \\
\hline$T, T_{0}$ & Temperature \\
\hline$\pi$ & $\mathrm{Pi}$ \\
\hline C & Specific Heat \\
\hline $\begin{array}{l}\text { A, B, C, a, b, } \\
\text { c, n }\end{array}$ & Constants \\
\hline M & Molecular weight of the base fluid \\
\hline $\mathrm{N}$ & Avogadro number \\
\hline$k_{\text {eff }}$ & Effective Thermal Conductivity \\
\hline$k_{p}$ & Thermal conductivity of particle \\
\hline$k_{f}$ & Thermal conductivity of fluid \\
\hline$k_{s}$ & Thermal conductivity of solids \\
\hline$D$ & Einstein diffusion coefficient \\
\hline $\mathrm{Re}$ & Reynolds Number \\
\hline $\operatorname{Pr}$ & Prandtl Number \\
\hline$T_{f r}$ & $\begin{array}{l}\text { Temperature of freezing point of the base } \\
\text { liquid }\end{array}$ \\
\hline$\lambda$ & Water molecules mean free path \\
\hline$\phi_{p}$ & Total particle volume fraction \\
\hline$V$ & Velocity \\
\hline$\phi_{T}$ & Total volume fraction \\
\hline
\end{tabular}




\section{Petroleum \& Petrochemical Engineering Journal}

\begin{tabular}{|l|l|}
\hline $\mathrm{P}$ & Pressure \\
\hline$\tau$ & Newtonian Base fluid \\
\hline $\mathrm{q}$ & Energy flux \\
\hline$h_{p}$ & Nanoparticle specific enthalpy \\
\hline$J$ & Mass flux \\
\hline
\end{tabular}

\section{References}

1. Kim DE, Dong IY, Jerngc DW, Kim MH, Ahn HS (2015) Review of boiling heat transfer enhancement on micro/ nanostructured surfaces. Experimental Thermal and Fluid Science 66: 173-196.

2. Xiang Qi W, Mujumdar AS (2007) Heat transfer characteristics of Nano fluids: a review. International journal of thermal sciences 46(1): 1-19.

3. Montes MJ, Abánades A, Martínez-Val JM, Valdésb M (2009) Solar multiple optimization for a solar-only thermal power plant, using oil as heat transfer fluid in the parabolic trough collectors. Solar energy 83(12): 2165-2176.

4. Montes MJ, Abánades A, Martínez-Val JM (2010) Thermofluidynamic model and comparative analysis of parabolic trough collectors using oil, water/steam, or molten salt as heat transfer fluids. Journal of solar energy engineering 132(2): 7.

5. Jones TB (1979) Electrohydrodynamically enhanced heat transfer in liquids-a review. Advances in heat transfer 14: 107-148.

6. Das SK, Stephen US Choi, Hrishikesh EP (2006) Heat transfer in Nano fluids-a review. Heat transfer engineering 27(10): 3-19.

7. Seyedeh-Saba A, Mohsen NE (2014) Mass transfer in Nano fluids: A review. International Journal of Thermal Sciences 82: 84-99.

8. Mohammed HA, Bhaskarana G, Shuaib NH, Saidur R (2011) Heat transfer and fluid flow characteristics in micro channels heat exchanger using Nano fluids: A review. Renewable and Sustainable Energy Reviews 15(3): 1502-1512.

9. Mohammed SK, Ferenc L (2019) Boiling heat transfer of Nano fluids: A review of recent studies. Thermal Science 23(1): 109-124.

10. Murshed SM, Sohel, Nieto DE (2016) Conduction and convection heat transfer characteristics of ethylene glycol based Nano fluids-a review. Applied energy 184: 681-695.

11. Zeeshan A, Pervaiz Z, Shehzad N, Nayak MK, Al-Sulami HH (2020) Optimal thermal performance of magnetoNano fluid flow in expanding/contracting channel. Journal of Thermal Analysis and Calorimetry.

12. Esfe MH, Bahiraei M, Hamid H, Valadkhani M (2020) A comprehensive review on convective heat transfer of Nano fluids in porous media: Energy-related and thermo hydraulic characteristics. Applied Thermal Engineering 178: 115487.

13. Xu HJ, Xing ZB, Wang FQ, Cheng ZM (2019) Review on heat conduction, heat convection, thermal radiation and phase change heat transfer of Nano fluids in porous media: Fundamentals and applications. Chemical Engineering Science 195: 462-483.

14. Raizah ZAS, Sameh EA, Abdelraheem MA (2020) ISPH simulations of natural convection flow in E-enclosure filled with a Nano fluid including homogeneous/ heterogeneous porous media and solid particles. International Journal of Heat and Mass Transfer 160: 120153.

15. Ahmed A, KambizV (2020) Analysis of particle deposition of Nano fluid flow through porous media. International Journal of Heat and Mass Transfer 161: 120227.

16. Sheikholeslami M, Zeeshan A (2017) Analysis of flow and heat transfer in water based Nano fluid due to magnetic field in a porous enclosure with constant heat flux using CVFEM. Computer Methods in Applied Mechanics and Engineering 320: 68-81.

17. Caton, Jerald A (2000) A review of investigations using the second law of thermodynamics to study internalcombustion engines. SAE transactions, pp: 1252-1266.

18. Ozawa H, Ohmura A, Lorenz RD, Pujol T (2003) The second law of thermodynamics and the global climate system: A review of the maximum entropy production principle. Reviews of Geophysics 41(4).

19. Udo S (2016) First and second law of thermodynamics at strong coupling. Phys Rev Lett 116(2): 020601.

20. Sangi R, Müller D (2019) Application of the second law of thermodynamics to control: A review. Energy 174: 938953.

21. Choi SUS, Eastman JA (1995) Enhancing thermal conductivity of fluids with nanoparticles. ASMEPublications-Fed 231: 99-106. 


\section{Petroleum \& Petrochemical Engineering Journal}

22. Khan WA, Pop I (2010) Boundary-layer flow of a nanofluid past a stretching sheet. International journal of heat and mass transfer 53(11-12): 2477-2483.

23. Chon CH, Kihm KD, Lee SP, Choi SU (2005) Empirical correlation finding the role of temperature and particle size for nanofluid $\left(\mathrm{Al}_{2} \mathrm{O}_{3}\right)$ thermal conductivity enhancement. Applied Physics Letters 87(15): 153107.

24. Kuznetsov AV, Nield DA (2010) Natural convective boundary-layer flow of a nanofluid past a vertical plate. International Journal of Thermal Sciences 49(2): 243-247.

25. Shah Z, Kumam P, Deebani W (2020) Radiative MHD Casson Nanofluid Flow with Activation energy and chemical reaction over past nonlinearly stretching surface through Entropy generation. Scientific Reports 10(1): 1-14.

26. Eastman JA, Choi SUS, Li S, Yu W, Thompson LJ (2001) Anomalously increased effective thermal conductivities of ethylene glycol-based nanofluids containing copper nanoparticles. Applied physics letters 78(6): 718-720.

27. Saif RS, Muhammad T, Sadia H, Ellahi R (2020) Hydromagnetic flow of Jeffrey nanofluid due to a curved stretching surface. Physica A: Statistical Mechanics and its Applications 551: 124060.

28. Keblinski P, Phillpot SR, Choi SUS, Eastman JA (2002) Mechanisms of heat flow in suspensions of nano-sized particles (nanofluids). International journal of heat and mass transfer 45(4): 855-863.

29. Kwak K, Kim C (2005) Viscosity and thermal conductivity of copper oxide nanofluid dispersed in ethylene glycol. Korea-Australia Rheology Journal 17(2): 35-40.

30. Tlili I, Nabwey HA, Reddy MG, Sandeep N, Pasupula M (2020) Effect of resistive heating on incessantly poignant thin needle in magnetohydrodynamic Sakiadis hybrid nanofluid. Ain Shams Engineering Journal.

31. Ellahi R, Hussain F, Abbas SA, Sarafraz MM, Goodarzi M, et al. (2020) Study of two-phase newtonian nanofluid flow hybrid with hafnium particles under the effects of slip. Inventions 5(1): 6.

32. Ullah I, Hayat T, Alsaedi A, Asghar S (2020) Modeling for radiated Marangoni convection flow of magnetonanoliquid subject to Activation energy and chemical reaction. Scientia Iranica 27(6): 3390-3398.

33. Dogonchi AS, Asghar Z, Waqas M (2020) CVFEM simulation for Fe304-H2O nanofluid in an annulus between two triangular enclosures subjected to magnetic field and thermal radiation. International Communications in Heat and Mass Transfer 112: 104449.

34. Majeed A, Zeeshan A, Bhatti MM, Ellahi R (2020) Heat transfer in magnetite $\left(\mathrm{Fe}_{3} \mathrm{O}_{4}\right)$ nanoparticles suspended in conventional fluids: Refrigerant-134A $\left(\mathrm{C}_{2} \mathrm{H}_{2} \mathrm{~F}_{4}\right)$, kerosene $\left(\mathrm{C}_{10} \mathrm{H}_{22}\right)$, and water $\left(\mathrm{H}_{2} \mathrm{O}\right)$ under the impact of dipole. Heat Transfer Research 51(3).

35. Zeeshan A, Maskeen MM, Mehmood OU (2018) Hydromagnetic nanofluid flow past a stretching cylinder embedded in non-Darcian Forchheimer porous media. Neural Computing and Applications 30(11): 3479-3489.

36. Khan MI, Hafeez MU, Hayat T, Khan MI, Alsaedi A (2020) Magneto rotating flow of hybrid nanofluid with entropy generation. Computer methods and programs in biomedicine 183: 105093.

37. Nield DA, Kuznetsov AV (2009) The Cheng-Minkowycz problem for natural convective boundary-layer flow in a porous medium saturated by a nanofluid. International Journal of Heat and Mass Transfer 52(25-26): 57925795.

38. Heris SZ, Esfahany MN, Etemad SG (2007) Experimental investigation of convective heat transfer of Al203/water nanofluid in circular tube. International Journal of Heat and Fluid Flow 28(2): 203-210.

39. Hassan M, Fetecau C, Majeed A, Zeeshan A (2018) Effects of iron nanoparticles' shape on convective flow of ferrofluid under highly oscillating magnetic field over stretchable rotating disk. Journal of Magnetism and Magnetic Materials 465: 531-539.

40. Huaxu L, Fuqiang W, Dong Z, Ziming C, Chuanxin Z, et al. (2020) Experimental investigation of cost-effective ZnO nanofluid based spectral splitting CPV/T system. Energy 194: 116913.

41. Hadadian M, Goharshadi EK, Youssefi A (2014) Electrical conductivity, thermal conductivity, and rheological properties of graphene oxide-based nanofluids. Journal of nanoparticle Research 16(12): 2788.

42. Chakraborty S, Panigrahi PK (2020) Stability of nanofluid: A review. Applied Thermal Engineering 174: 115259.

43. Sheikholeslami M, Zeeshan A, Majeed A (2018) Control volume based finite element simulation of magnetic nanofluid flow and heat transport in non-Darcy medium. Journal of Molecular Liquids 268: 354-364.

44. Otanicar TP, Phelan PE, Prasher RS, Rosengarten G, 


\section{Petroleum \& Petrochemical Engineering Journal}

Taylor RA (2010) Nanofluid-based direct absorption solar collector. Journal of renewable and sustainable energy 2(3): 033102.

45. Nadeem S, Abbas N, Malik MY (2020) Inspection of hybrid based nanofluid flow over a curved surface. Computer Methods and Programs in Biomedicine 189: 105193.

46. Shehzad N, Zeeshan A, Ellahi R (2018) Electroosmotic Flow of MHD Power Law Al203-PVC Nanouid in a Horizontal Channel: Couette-Poiseuille Flow Model. Communications in Theoretical Physics 69(6): 655.

47. Ferrouillat S, Bontemps A, Poncelet O, Soriano O, Gruss JA (2011) Influence of nanoparticle shape factor on convective heat transfer of water-based $\mathrm{ZnO}$ nanofluids: performance evaluation criterion. Int J Mech Ind Eng 1(2): 7-13.

48. Yu W, Choi SUS (2003) The role of interfacial layers in the enhanced thermal conductivity of nanofluids: a renovated Maxwell model. Journal of nanoparticle research 5(1-2): 167-171.

49. Maxwell JC (1873) Electricity and Magnetism Clarendon Press. Oxford, UK.

50. Hamilton RL, Crosser OK (1962) Thermal conductivity of heterogeneous two-component systems. Industrial \& Engineering chemistry fundamentals 1(3): 187-191.

51. Harris Peter JF (2004) Carbon nanotubes and related structures: new materials for the twenty-first century. Cambridge University Press, pp: 415-415.

52. Odom TW, Huang JL, Kim P, Lieber CM (2000) Structure and electronic properties of carbon nanotubes. J Phys Chem B 104(13): 2794-2809.

53. Kalamkarov, AL, Georgiades AV, Rokkam SK, Veedu VP, Ghasemi-Nejhad MN (2006) Analytical and numerical techniques to predict carbon nanotubes properties. International journal of Solids and Structures 43(22-23): 6832-6854.

54. O'connell, Michael J. (2006) Carbon nanotubes: properties and applications. CRC press.

55. Thostenson ET, Ren Z, Tsu-Wei C (2001) Advances in the science and technology of carbon nanotubes and their composites: a review. Composites science and technology 61(13): 1899-1912.

56. Trojanowicz M (2006) Analytical applications of carbon nanotubes: a review. TrAC trends in analytical chemistry 25(5): 480-489.
57. Belin T, Florence E (2005) Characterization methods of carbon nanotubes: a review. Materials Science and Engineering: B 119(2): 105-118.

58. Dave UC, Ingale DV, Venkatesh K, Krishna Bayineni V, Kadeppagari RK (2017) Multiwalled carbonnanotubes enhance the response and sensitivity of the ammonium biosensor based on alanine dehydrogenase. Journal of Electroanalytical Chemistry 784: 102-108.

59. Matsumoto T, Komatsu T, Nakano H, Arai K, Nagashima $Y$, et al. (2004) Efficient usage of highly dispersed Pt on carbon nanotubes for electrode catalysts of polymer electrolyte fuel cells. Catalysis Today 90(3-4): 277-281.

60. Ellahi R, Hassan M, Zeeshan A (2015) Study of natural convection MHD nanofluid by means of single and multiwalled carbon nanotubes suspended in a salt-water solution. IEEE Transactions on Nanotechnology 14(4): 726-734.

61. Majeed A, Zeeshan A, Mubbashir S (2019) Vibration analysis of carbon nanotubes based on cylindrical shell by inducting Winkler and Pasternak foundations. Mechanics of Advanced Materials and Structures 26(13): 11401145.

62. Masuda H, Ebata A, Teramae K (1993) Alteration of thermal conductivity and viscosity of liquid by dispersing ultra-fine particles. Netsu Bussei 7(4): 227-233.

63. Eastman JA (1999) Novel thermal properties of nanostructured materials (No. ANL/MSD/CP-96711). Argonne National Lab., IL (US).

64. Lee S, Choi SS, Li SA, Eastman JA (1999) Measuring thermal conductivity of fluids containing oxide nanoparticles. Journal of Heat transfer 121(2): 280-289.

65. Wang X, Xu X, Choi SUS (1999) Thermal conductivity of nanoparticle-fluid mixture. Journal of thermophysics and heat transfer 13(4): 474-480.

66. Xie H, Wang J, Xi T, Liu Y, Ai F, et al. (2002) Thermal conductivity enhancement of suspensions containing nanosized alumina particles. Journal of applied physics 91(7): 4568-4572.

67. Xie H, Wang J, Xi T, Liu Y, Ai F (2002) Dependence of the thermal conductivity of nanoparticle-fluid mixture on the base fluid. Journal of Materials Science Letters 21(19): 1469-1471.

68. Das SK, Putra N, Thiesen P, Roetzel W (2003) Temperature dependence of thermal conductivity enhancement for nanofluids. Journal of heat transfer 125(4): 567-574. 


\section{Petroleum \& Petrochemical Engineering Journal}

69. Putra N, Roetzel W, Das SK (2003) Natural convection of nano-fluids. Heat and mass transfer 39(8-9): 775-784.

70. Wen D, Ding Y (2004) Experimental investigation into convective heat transfer of nanofluids at the entrance region under laminar flow conditions. International journal of heat and mass transfer 47(24): 5181-5188.

71. Nara S, Bhattacharya P, Vijayan P, Lai W, Phelan P, et al. (2005) ASME International Mechanical Engineering Congress and Exposition. Orlando, FL, USA, 80524.

72. Chon CH, Kihm KD, Lee SP, Choi SU (2005) Empirical correlation finding the role of temperature and particle size for nanofluid $\left(\mathrm{Al}_{2} \mathrm{O}_{3}\right)$ thermal conductivity enhancement. Appl Phys Lett 87(15): 153107.

73. Li CH, Peterson GP (2006) Experimental investigation of temperature and volume fraction variations on the effective thermal conductivity of nanoparticle suspensions (nanofluids). Journal of Applied Physics 99(8): 084314.

74. Krishnamurthy S, Bhattacharya P, Phelan PE, Prasher RS (2006) Enhanced mass transport in nanofluids. Nano letters 6(3): 419-423.

75. ZhangX,GuH,FujiiM(2006)Effectivethermal conductivity and thermal diffusivity of nanofluids containing spherical and cylindrical nanoparticles. Journal of Applied Physics 100(4): 044325.

76. He Y, Jin Y, Chen H, Ding Y, Cang D, et al. (2007) Heat transfer and flow behaviour of aqueous suspensions of $\mathrm{TiO}_{2}$ nanoparticles (nanofluids) flowing upward through a vertical pipe. International journal of heat and mass transfer 50(11-12): 2272-2281.

77. Li CH, Peterson GP (2007) The effect of particle size on the effective thermal conductivity of $\mathrm{Al}_{2} \mathrm{O}_{3}$-water nanofluids. Journal of Applied Physics 101(4): 044312.

78. Anoop KB, Sundararajan T, Das SK (2009) Effect of particle size on the convective heat transfer in nanofluid in the developing region. International journal of heat and mass transfer 52(9-10): 2189-2195.

79. Vajjha RS, Das DK, Namburu PK (2010) Numerical study of fluid dynamic and heat transfer performance of $\mathrm{Al} 2 \mathrm{O} 3$ and $\mathrm{CuO}$ nanofluids in the flat tubes of a radiator. International Journal of Heat and fluid flow 31(4): 613-621.

80. Patel HE, Sundararajan T, Das SK (2010) An experimental investigation into the thermal conductivity enhancement in oxide and metallic nanofluids. Journal of Nanoparticle Research 12(3): 1015-1031.
81. Teng TP, Hung YH, Teng TC, Mo HE, Hsu HG (2010) The effect of alumina/water nanofluid particle size on thermal conductivity. Applied Thermal Engineering 30(14-15): 2213-2218.

82. Akbulut $\mathrm{M}$, Alig ARG, Min Y, Belman N, Reynolds $M$, et al. (2007) Forces between surfaces across nanoparticle solutions: role of size, shape, and concentration. Langmuir 23(7): 3961-3969.

83. Timofeeva EV, Routbort JL, Singh D (2009) Particle shape effects on thermophysical properties of alumina nanofluids. Journal of Applied Physics 106(1): 014304.

84. Cui W, Bai M, Lv J, Li G, Li X (2011) On the influencing factors and strengthening mechanism for thermal conductivity of nanofluids by molecular dynamics simulation. Industrial \& Engineering Chemistry Research 50(23): 13568-13575.

85. Ghosh MM, Ghosh S, Pabi SK (2013) Effects of particle shape and fluid temperature on heat-transfer characteristics of nanofluids. Journal of materials engineering and performance 22(6): 1525-1529.

86. Pilkington GA, Briscoe WH (2012) Nanofluids mediating surface forces. Advances in colloid and interface science 179-182:, 68-84.

87. Ooi EH, Popov V (2013) Numerical study of influence of nanoparticle shape on the natural convection in $\mathrm{Cu}$-water nanofluid. International Journal of Thermal Sciences 65: 178-188.

88. Ferrouillat S, Bontemps A, Poncelet O, Soriano O, Gruss JA (2013) Influence of nanoparticle shape factor on convective heat transfer and energetic performance of water-based $\mathrm{SiO}_{2}$ and $\mathrm{ZnO}$ nanofluids. Applied thermal engineering 51(1-2): 839-851.

89. Vajjha RS, Das DK (2009) Experimental determination of thermal conductivity of three nanofluids and development of new correlations. International Journal of Heat and Mass Transfer 52(21-22): 4675-4682.

90. Pak BC, Cho YI (1998) Hydrodynamic and heat transfer study of dispersed fluids with submicron metallic oxide particles. Experimental Heat Transfer an International Journal 11(2): 151-170.

91. Handbook ASHRAE, American Society of Heating. Refrigeration and Air-Conditioning Engineers, Inc.

92. Buongiorno J (2006) Convective transport in nanofluids. Journal of heat transfer 128(3): 240-250. 


\section{Petroleum \& Petrochemical Engineering Journal}

93. Einstein A (1906) Eine neue bestimmung der moleküldimensionen. Annalen der Physik 324(2): 289306.

94. Xu HJ, Xing ZB, Wang FQ, Cheng ZM (2018) Review on Heat Conduction, Heat Convection, Thermal Radiation and Phase Change Heat Transfer of Nanofluids in Porous Media: Fundamentals and Applications. Chemical Engineering Science 195: 462-483.

95. Yu W, France DM, Routbort JL, Choi SU (2008) Review and comparison of nanofluid thermal conductivity and heat transfer enhancements. Heat transfer engineering 29(5): 432-460.

96. Ghadimi A, Saidur R, Metselaar HSC (2011) A review of nanofluid stability properties and characterization in stationary conditions. International journal of heat and mass transfer 54(17-18): 4051-4068.

97. Kleinstreuer C, Feng Y (2011) Experimental and theoretical studies of nanofluid thermal conductivity enhancement: a review. Nanoscale research letters 6(1): 229.

98. Li Y, Tung S, Schneider E, Xi S (2009) A review on development of nanofluid preparation and characterization. Powder technology 196(2): 89-101.

99. Saitô N (1950) Concentration dependence of the viscosity of high polymer solutions. I. J Phys Soc Jpn 5(1): 4-8.

100. Brinkman HC (1952) The viscosity of concentrated suspensions and solutions. The Journal of Chemical Physics 20(4): 571.

101. Lundgren TS (1972) Slow flow through stationary random beds and suspensions of spheres. Journal of Fluid Mechanics 51(2): 273-299.

102. Batchelor GK (1977) The effect of Brownian motion on the bulk stress in a suspension of spherical particles. Journal of fluid mechanics 83(1): 97-117.

103. Drew DA, Passman SL (2006) Theory of multicomponent fluids. $1^{\text {st }}$ (Edn.), Springer Science \& Business Media, pp: 310.

104. Tseng WJ, Lin KC (2003) Rheology and colloidal structure of aqueous $\mathrm{TiO} 2$ nanoparticle suspensions. Materials science and engineering: A 355(1-2): 186-192.

105. Maiga SEB, Palm SJ, Nguyen CT, Roy G, Galanis N (2005) Heat transfer enhancement by using nanofluids in forced convection flows. International journal of heat and fluid flow 26(4): 530-546.

106. Maïga SEB, Nguyen CT, Galanis N, Roy G (2004) Heat transfer behaviours of nanofluids in a uniformly heated tube. Superlattices and Microstructures 35(3): 543-557.

107. Song S, Peng C, Gonzalez-Olivares MA, LopezValdivieso A, Fort T (2005) Study on hydration layers near nanoscale silica dispersed in aqueous solutions through viscosity measurement. Journal of colloid and interface science 287(1): 114-120.

108. Koo J, Kleinstreuer C (2005) Impact analysis of nanoparticle motion mechanisms on the thermal conductivity of nanofluids. International Communications in Heat and Mass Transfer 32(9): 1111-1118.

109. Kulkarni DP, Das DK, Chukwu GA (2006) Temperature dependent rheological property of copper oxide nanoparticles suspension (nanofluid). Journal of nanoscience and nanotechnology 6(4): 1150-1154.

110. Chen H, Ding Y, He Y, Tan C (2007) Rheological behaviour of ethylene glycol based titania nanofluids. Chemical physics letters 444(4-6): 333-337.

111. Nguyen CT, Desgranges F, Roy G, Galanis N, Maré T, et al. (2007) Temperature and particle-size dependent viscosity data for water-based nanofluids-hysteresis phenomenon. International Journal of Heat and Fluid Flow 28(6): 1492-1506.

112. Namburu PK, Kulkarni DP, Misra D, Das DK (2007) Viscosity of copper oxide nanoparticles dispersed in ethylene glycol and water mixture. Experimental Thermal and Fluid Science 32(2): 397-402.

113. Namburu PK, Kulkarni DP, Misra D, Das DK (2007) Viscosity of copper oxide nanoparticles dispersed in ethylene glycol and water mixture. Experimental Thermal and Fluid Science 32(2): 397-402.

114. Masoumi N, Sohrabi N, Behzadmehr A (2009) A new model for calculating the effective viscosity of nanofluids. Journal of Physics D: Applied Physics 42(5): 055501.

115. DuangthongsukW,WongwisesS(2009)Measurement of temperature-dependent thermal conductivity and viscosity of TiO2-water nanofluids. Experimental thermal and fluid science 33(4): 706-714.

116. Chandrasekar M, Suresh S, Bose AC (2010) Experimental investigations and theoretical determination of thermal conductivity and viscosity of Al203/water nanofluid. Experimental Thermal and 


\section{Petroleum \& Petrochemical Engineering Journal}

Fluid Science 34(2): 210-216.

117. Corcione M (2011) Rayleigh-Bénard convection heat transfer in nanoparticle suspensions. International Journal of Heat and Fluid Flow 32(1): 65-77.

118. Bruggeman VD (1935) Berechnung verschiedener physikalischer Konstanten von heterogenen Substanzen. I. Dielektrizitätskonstanten und Leitfähigkeiten der Mischkörper aus isotropen Substanzen. Annalen der physic 416(7): 636-664.

119. Wasp FJ (1977) Solid-liquid slurry pipeline transportation. Transactions on Techniques, Berlin.

120. Davis RH (1986) The effective thermal conductivity of a composite material with spherical inclusions. International Journal of Thermophysics 7: 609-620.

121. Lu S, Lin H (1996) Effective conductivity of composites containing aligned spherical inclusions of finite conductivity. Journal of Applied Physics 79: 67616769.

122. Xue QZ (2003) Model for effective thermal conductivity of nanofluids. Physics Letters A 307(5-6): 313-317.

123. Bhattacharya PSSK, Saha SK, Yadav A, Phelan PE, Prasher RS (2004) Brownian dynamics simulation to determine the effective thermal conductivity of nanofluids. Journal of Applied Physics 95(11): 64926494.

124. Koo J, Kleinstreuer C (2004). A new thermal conductivity model for nanofluids. Journal of Nanoparticle Research 6(6): 577-588.

125. Koo J, Kleinstreuer C (2005) Laminar nanofluid flow in micro heat-sinks. International Journal of Heat and Mass Transfer 48(13): 2652-2661.

126. Prasher R, Bhattacharya P, Phelan PE (2005) Thermal conductivity of nanoscale colloidal solutions (nanofluids). Physical review letters 94(2); 025901.
127. Xue QZ (2005) Model for thermal conductivity of carbon nanotube-based composites. Physica B: Condensed Matter 368(1-4): 302-307.

128. Xue Q, Xu WM (2005) A model of thermal conductivity of nanofluids with interfacial shells. Materials Chemistry and Physics 90(2-3): 298-301.

129. Xie H, Fujii M, Zhang X (2005) Effect of interfacial nanolayer on the effective thermal conductivity of nanoparticle-fluid mixture. International Journal of Heat and Mass Transfer 48(14): 2926-2932.

130. LiCH,Peterson GP (2006) Experimental investigation of temperature and volume fraction variations on the effective thermal conductivity of nanoparticle suspensions (nanofluids). Journal of Applied Physics 99(8): 084314

131. Timofeeva EV, Gavrilov AN, McCloskey JM, Tolmachev YV, Sprunt S, et al. (2007) Thermal conductivity and particle agglomeration in alumina nanofluids: experiment and theory. Physical Review E 76(6): 061203.

132. Avsec J, Oblak M (2007) The calculation of thermal conductivity, viscosity and thermodynamic properties for nanofluids on the basis of statistical nanomechanics. International Journal of Heat and Mass Transfer 50(21-22): 4331-4341.

133. Chandrasekar M, Suresh S, Srinivasan R, Bose AC (2009) New analytical models to investigate thermal conductivity of nanofluids. Journal of nanoscience and nanotechnology 9(1): 533-538.

134. Godson L, Raja B, Lal DM, Wongwises S (2010) Experimental investigation on the thermal conductivity and viscosity of silver-deionized water nanofluid. Experimental Heat Transfer 23(4): 317-332.

135. Tiwari RK, Das MK (2007) Heat transfer augmentation in a two-sided lid-driven differentially heated square cavity utilizing nanofluids. International Journal of Heat and Mass Transfer 50(9-10): 2002-2018. 